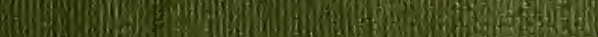

(3)

(19.5.

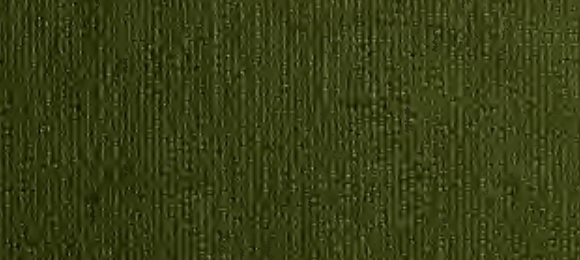

(4) An U. (1)

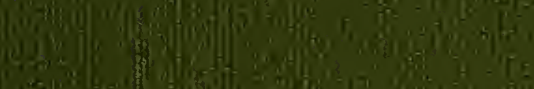
J. (1) (19) (3) Ifoud (in $)$ (n)

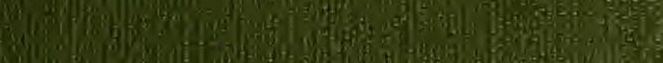

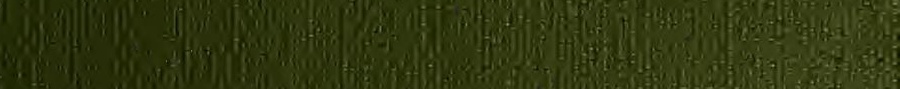

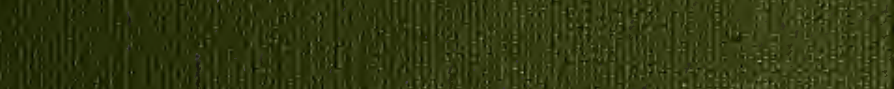
Ine

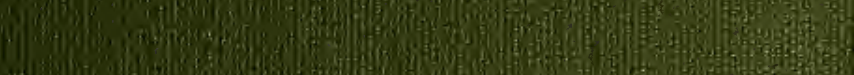

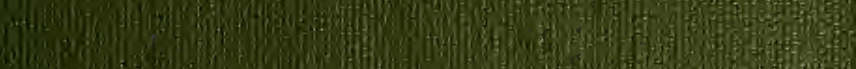

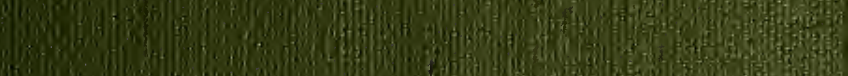
(2) 
Cooper He nut pruseum Libragy.

New York, New York 19923 






\section{Ancient Mexico in Miniature}

Pre-Columbian Clay Figures from the Collection of Frances Pratt and Bumpei Usui

COOPER UNION MUSEUM

June 20th through August 19th, 1966 
943271 
ANCIENT IEXICO IN MINIATURE

As exemplified in the srall clay sculpture of Mexico, probably no other people of ancient times left such a tangible record of their daily life, both secular and religious. Ceramic art was highly developed as early as 1500 B.C., in the Valley of llexico, and the tradition was widespread throughout the . . . country until the Spanish Conquest in 1521.

With the exeption of nold-made pieces produced fron late liaya through Aztec tires, miniature sculpture was freely modeled. Pre-Classic figures, or those dating beforc or around the first sentury of the Christian era, relied heavily on a technique of rolling pellets of clay and appliqueinf them on the main body as facial features and adornments. It is interesting to note the finesse with which elaborate coiffures and jewlery were executed, and the arparent regard in which high fashion was held. Though probably significant as fertility fifures, those fron Tlatilco, Chupicuaro and lichoacan reflect a stylishly coiffed and ornanented, though otherwise, nude people.

After the first century A.D., a great variety of genre work, illustrating daily life, was produced in ilestern liexico, particularly in the states of Colina, Nayarit and Jalisco. While applique was still used, forns were inclined to be more fully expanded, and there was increased use of color and burnishing.

Figurativie work from the Vera Cruz area represents a number of periods, from the early, simplified Panuco figure through later, naturalistic ceremonial representations. It is generally true that the later works reflected a more sophisticated religious concept. This is apparent in the Aztec period where temples and important personages were frequently portrayed. 

ANCIENT ITEXICO IN I'INIATU:IE

Apart from their story-telling significace, Pre-Colurbian miniatures have an aosthetictappoal due, in large measure, to the reverent convictions of their nakers. The figures transcend time and place to make a universally recognizable artistic statement.

Frances Pratt 

From Valley of Nexico

Pre-Classic period (c. 1500 - 500 B.C.)

1. STANDING "GHOST" FIGURE

Canitas, 2 1/4"

2. STAIDIHG FIGURE (Olmec)

Puebla, $41 / 8$ "

3. STINDING FIG:RE

Tlatilco, $33 / 8$ "

4. ELONGATED FEILLE FIGURE

Tlapacoya, 4"

5. STANDING FEjALE FIGURE IITH SKIRT Titatiteo; $3: 1 / 4 "$ "

6. FEMALE DANCER Titatico, $31 / 8$ i

7. STANDING FIGURE
$13 / 4 "$

8. DOUBLE HEADED FIGURE

$17 / 8$ "

9. STANDING TIGURE

Tlatilco, 2 1/2"

10. STANDING FIFURE WITH LEAF CROWN Tlatilco, $43 / 8$ "

11. AIIriaL (Tejon)

Tlatilco, I"

12. SEATED FIGURE

Tlapacoya, 2"

13. STANDING FIGURE IITH WHASK

Michoacan, 4"

14. STANDING FIGURE, HANDS OIN HAIP

Michoacan, $37 / 8$ "

15. DOGS, RUNNING

Michoacan, $13 / 4$ "
16. STANDING FIGURE, DOUBLE HELDED

$$
\mathrm{B}_{2} \mathrm{BY}
$$

lichoacan, $13 / 4$ "

17. STANDING FIGURE, BRAIDED

HEADDRESS

Chupicuaro, $43 / 8$ "

18. STANDING FIGURD UIT' FLO:.ER

EA RRINGS

lichoacan, 4"

19. STAIDING FIGURD WITH TURBAN lichoacan, $43 / 4$ "

20. SEATTD FEIALE FIGURE WITH HEADDR ISS

Cuanalan, 2 1/8"

From State of Guanajuato

Late Pre-Classic period (c. 400 B.C. 100 H.D.)

21. STANDING FIGURS, $f_{2}$ Ri: UPR ISED

Chupicuaro, 2 1/2"

22. STANDING FIGUR

Xalos toc, $23 / 8$ "

23. STANDING FIGURE

Chupicuaro, 4"

$\therefore$

From Valley of Vexico

Pre-Classic period (c. 1500-500 B.C.)

24. STANDING FEISLE FIGURE

El Arbolillo, $51 / 4 "$

25. FIGURE IN REGaLIA

Tlapacoya, 6 I/ 4 " 



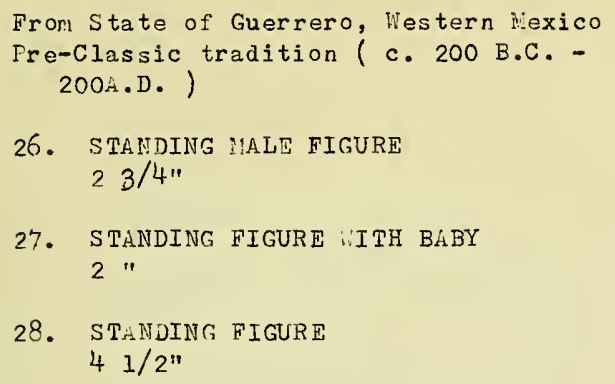

$$
21 / 2 "
$$

31. DOG

$$
17 / 8 "
$$

32. DOG

$$
13 / 4^{\prime \prime}
$$

33. STANDING FIGURE HOLDING BABY $33 / 4 "$

34. SEATED NOTHER IITH BMY $A N D$ 4" SUHSHAD

35. CHILD STATED ON is STOOL

$$
23 / 8 "
$$

36. A PUP: $Y$ $3 / 4 "$

37. BABY IN CRIB
$11 / 8$ "

38. NOTHER HOLDING BABY

$$
21 / 2^{\prime \prime}
$$

39. WHISTLE IN THE FORI OF A WARRIOR FIGURE 4"

40. WARRIOR WITH SHIELD 4"

41. TWO-NEN FLAYING A DRUS

$$
21 / 4 "
$$

42. WHISTLI IN THE FORH OF STRONG . IAN

$17 / 8$ "

43. WHISTLE IN THE FOR , OF STRONG I:AN

$21 / 8 "$

44. A GHFEF IN E PALLNELIN. CEIEF $17 / 8$ " PALENQUIN $31 / 8$ "

45. WHISTLE IN THE FORL OF STRONG $1.4 \mathrm{~N}$
$3 / 811$

46. WHISTLE IN THE FORT OF STRONG : MiAN

$21 / 8 "$

47. WHESTLE IN: THE IORM OF :STRONG IAAN

$21 / 2 "$

48. HHISTE IN THE FORN OF HUNCHBACK $21 / 2^{\prime \prime}$

49. HHISTLE IN THE FORYA OF SEATD FIGURE

$21 / 2 "$

GROUP OF SEVEN DANCERS:

50. $37 / 8 "$

51. $33 / 8$ " 

52. $33 / 8$ "

53. $31 / 4 "$

$54.31 / 2^{\prime \prime}$

$55.31 / 2^{\prime \prime}$

$56.33 / 4 "$

57. A DRUIMLR

$21 / 8 "$

58. VHISTLE IN THE FORI OF A BIRD $21 / 2^{\prime \prime}$

59. WHISTLE IN THE FORN OF A $\mathrm{i}+\mathrm{N}$ VITH A FISH'S HELD

3 3/8"

60. BOUND FIGURE .ITH \& DOG I"

6I. STANDING FIGUKE $47 / 8 "$

GROUP OF THREE RECLINING FIGURES:

62. 2"

63. $21 / 2^{\prime \prime}$

$64.23 / 4$ "

65. $\mathrm{CROBAT}$

$21 / 4 "$

66. THREI FIGURES PERFORIIIG h RITE 4 "1

67. A COUPLE ENBRACING $2^{\prime \prime}$

68. PEHCOCK ITH DOG $41 / 4 "$

69. MHISTLE IN THE FORI OF A HDACOCK WITH DOG

$41 / 2^{\prime \prime}$

70. FIGURE SEATED ON A STOOL $41 / 2^{n}$

71. AN AFFECTIONATE FAIILY: FATHER, MOTHER aND BitBY ( Baby's head is missing )

$31 / 8$ "
72. WHISTLE IN THE FOR! OF FIGURE

WITH PLETE HND JAR $3^{\prime \prime}$

73. STANDING COUPLE $51 / 4 "$

74. SEATED COUPLE $33 / 8 "$

Fron State of Nayarit, Western liexico Early Classic period (c. 300-600.A:D.?

75. DOG STANDING ON HEAD OF $\mathrm{t}$ STATID FIGURE

$33 / 8 "$

76. VESSEL IN THE FORN OF A SEATED COU上 LE

$31 / 8 "$

77. FATH HR HOLDING HIS SON ON HIS SHOULDERS

$43 / 4$ "

78. SEATED FIGURE VERING A FANCY CAPE

$23 / 4 "$

79. SEHTED FIGURE IITH TWO DOGS $33 / 8 "$

80. SEATED FIGURE DRINKING FROI

A BOWL THROUGH A TUBE $33 / 4 "$

81. SEATED FIGURE WITH \& Bis BY

(Chinesco)

$31 / 4$ "

82. SEATED FIGURD UITH SHIELD

(Chinesco)

$27 / 8 "$

83. SEITED FIGURE ATH BABY

$($ Chinesco)
$43 / 8 "$ 


\section{STATRD FIGURE (Chinesco) $23 / 8$ " \\ 85. STATID FIGURE PLAYING MUSICAL INSTRUIIEN? \\ $33 / 4^{\prime \prime}$}

86. VHISTLE IN THE FORIN OF A COILED SNAKE $3 / 4 "$

87. SEATED FIGURE IITI PARASOL AND DOG $51 / 4^{\prime \prime}$

88. CURLED UP DOG
I $1 / 2$ "

89. RECUMBENT FIGURE WITEI ATTEIDANT $23 / 4 "$

From State of Jalisco, Western hico Early Clasic period (c. 300-600 A.D.) or earlier

90. SEHE; JOTHER AND BABY $51 / 8$ "

91. STANDING FIGURE 4"

92. STANDING FIGURE WEARING IARRINGS AND NECKLACE

$$
33 / 4 "
$$

93. SEATED MOTHER AND BABY $41 / 2 "$

94. SEATED FIGURE OF WONAN, IITH A LONG NOSE

$51 / 4^{\prime \prime}$

95. NALT FIGURT

$27 / 8 "$

96. FE: ALE FIGURE $31 / 2^{\prime \prime}$
97. SEFTED FIGURE HOLDING A FLOHIR $31 / 2^{\prime \prime}$

From State of Vera Cruz Classic period (c. 300-600 i.D.)

Figures 98-105, 107-109, 112 \&

116, fron Renojadas

98. SETED 1ONKEY, EATING

$31 / 2^{\prime \prime}$

99. SMALL IONKEY

$11 / 4^{\prime \prime}$

100. NOUSI

2"

101. I.ONKEY

$31 / 2^{\prime \prime}$

102. FIGURE ?EARING A HELIIIT $31 / 2 "$

103. FICURE WE RINTG A HAT $41 / 4 "$

104. FIGURE NWRING \& CAIT hND HELI:ET

$33 / 8 "$

105. SEATES WN ITTH ARIS CROS ED ON KNEES

$31 / 2^{\prime \prime}$

106. FIGURE WRARIIJG BIRD TASK $31 / 2^{\prime \prime}$

107. FIGURE WEARING ANIIAL WASK AND HOLDING :USICAL INSTRUNEIT $47 / 8$ "

108. FIGURE, POSSIBLY LN EXECUTIONER $37 / 8 "$

109. FIGURE WHRING A BIRD HASK $41 / 2 "$ 

110. A WHISTLE

$43 / 8 "$

111. A IHISTLE

$3^{\prime \prime}$

112. NOTHER AND BABY

$41 / 2 "$

113. FIGURATIVE WISTLE

$21 / 4 "$

114. A WHISTLE

$31 / 2$ "

115. A WHISTLE

$$
31 / 4 "
$$

116. WHISTLE

$41 / 2^{\prime \prime}$

117. FIGURE NITH ELEPIIANT NASK

$41 / 2 "$

118. FIGURE WDARING ANIYAL NASK $41 / 8$ "

119. HISTLE IN THE FORI OF A B.T $31 / 2 "$

120. FANTASTIC FIGURT $41 / 2 "$

121. FANTASTIC FIGURD 4"

From Valley of lexico

Pre-Classic tradition (c. 200 B.C. 200 A.D.)

122. SDATED FIGURE VITH FEATHERS

Teotihuacan, $2^{\prime \prime}$

123. SRATED FIGURE

Teotihuacan, 2 1/8"

124. STTED FIGURE

Teotihuacan, 1 1/2"
125. ST NDING FIGURE

Teotihuacan, $43 / 8$ "

126. STANUING PIGURE

Teotihuacan, $43 / 8$ "

127. SATED FIGURE WERRING CAFE Teotihuacan, 3"

128. SETAD FIGURE WR RING A HAT Teotihuacan, $21 / 2 "$

129. STANDING FIGURE TRERING CAPE AND VIDE HAT

Teotihuacan, $53 / 8$ "

130. SEATED FIGURE BLOIIING ON $A$ $\mathrm{CONCH}$

Toditituacan, $23 / 4 "$

131. IUSICAL INSTRUI'ENT IN THE FORI OF A ST $T_{\alpha}$ INDING FIGURE

Teotihuacan, $41 / 2$ "

From State of Yucatan

(c. 700 - 1000 A.D.)

132. OVL

1.aya, $31 / 8$ "

133. OHL

liaya, $33 / 4$ "

134. FIGURE OF AN OFITCIAL

(Island of Jaina)

laya, $31 / 8$ "

From Valley of hiexico and State of

Vera Cruz

$(1300-1500$ A.D. )

135. SETD FIGURE Aztec, 4 5/8"

136. SEATED FIGURE Aztec, 4 5/8" 

137. MINIATURE TEMPLE SURIOUNTED BY

VIND GOD

Aztec, $31 / 4$ "

138. STATUETTE OF WIND GOD

Aztec, $31 / 8$ "

139. SIATED FIGURE

Aztec, $43 / 4$ "

140. DOUBLE TEMPLE

Aztec, 3 3/4"

141. TELPE IITH A STEEP RUOF

Aztec, 3 3/4"

142. TEI:PLE "ITH A FEKKED ROOF

Aztec, 4"

143. ROUND TMIPLE IITH A STEEP ROOF Aztec, 4"

144. ROUND TEPIPLE

Aztec, 3 3/4"

145. DOUBLE TEIPLE Aztec, 3 3/8"

146. HIND GOD ON TEIPLE

Aztec, $61 / 2^{\prime \prime}$

147. ROUND TASIPLE Aztec, $37 / 8$ "

148. TEMPLE ITH CONICAI ROOF Aztec, 5" 





